\title{
Research on Impact of Listed Companies Sustainable Development on Company's Value
}

\author{
Indre Lapinskaite ${ }^{1}$, Algita Miecinskiene ${ }^{2}$, Ausra Michejeva ${ }^{3}$ \\ Department of Financial Engineering, Faculty of Business Management, \\ Vilnius Gediminas Technical University, Vilnius, Lithuania \\ E-mails: ${ }^{1}$ indre.lapinskaite@vgtu.lt (correspondingauthor);2algita.miecinskiene@vgtu.lt; \\ 3ausra.michejeva@stud.vgtu.lt
}

Received 26 February 2017; accepted 07 April 2017

\begin{abstract}
Sustainable development is not only hardly measurable phenomenon, but it is also quite a challenge to determine its impact on the company's activities and the results. The scientific literature presents lot of areas reflecting sustainable development, but there is no definite opinion how to quantify the impact of sustainable development for listed companies' value. Proper assessment of sustainable development is particularly important in order to represent the company and to attract new investors. The purpose of this paper is to evaluate what kind of impact sustainable development has on the value of listed companies. According to the results of scientific literature, two hypotheses were proposed: (H1) Sustainable development of listed company has an impact on the company's weighted average capital costs, and it has a reflection in company's value. (H2) The results of sustainable development activities are seen in indices of company's value assessment. The hypotheses were verified by evaluating companies which are listed in NASDAQ OMX BALTIC stock exchange and participate in UN Global Compact. The research shows different results for both hypotheses, $\mathrm{H} 1$ could be approved and only two of the three companies of $\mathrm{H} 2$ results confirmed the hypothesis.
\end{abstract}

Keywords: sustainable development, value of listed company, economic value added, the ratio of enterprise value and earnings before interest, tax, depreciation and amortization, return on equity, weighted average cost of capital.

JEL Classification: G31, Q01.

Conference topic: Contemporary Financial Management.

\section{Introduction}

The reasons why business units implement ideology of sustainable development in its activities are different. Some strive to maintain their value in the market, while others try to raise their competitiveness, others prefer to take care about social and environmental media and by invoking the resources of economic medium pursue an ideology of sustainable development. However, it should be noted that sustainable development is not only hardly tangible, measurable phenomenon, but it is also quite a challenge to determine its impact on the company's activities and the results.

There are a number of alternative methods and indices for value assessment, but a problem arises when the method should be chosen for the company in which the concept of sustainable business is actively developed. The scientific literature presents lot of areas reflecting sustainable development, but there is no definite opinion how to quantify the impact of sustainable development for listed companies' value.

Lithuanian experience shows that business units are still reluctant to provide reports of sustainable development. This situation leads to the fact that this area has not been regulated by any legislation so far, and only based on voluntary initiatives. Also exist the fact that business units, which implement sustainable development perhaps would like to provide reports of sustainable development, however they do not always know how to measure sustainable development activities objectively due to different types of value and diversity of potential recipients of value. Proper assessment of sustainable development is particularly important in order to represent the company to the public positively and to attract new investors. This problem arises the question: How to evaluate the impact of the sustainable development on the value of listed companies?

Main purpose of this paper is to evaluate what kind of impact sustainable development has on the value of listed companies.

(C) 2017 I. Lapinskaite, A. Miecinskiene, A. Michejeva. Published by VGTU Press. This is an open-access article distributed under the terms of the Creative Commons Attribution (CC BY 4.0) License, which permits unrestricted use, distribution, and reproduction in any medium, provided the original author and source are credited. 

company's value

First of all, theoretic aspects of sustainable development's impact on listed companies' value has been overviewed, later the relationship of sustainable development and value creation has been analysed. According to analysis results, the hypotheses were proposed:

H1: sustainable development of listed company has an impact on the company's weighted average capital costs, and it has a reflection in company's value.

$\mathrm{H} 2$ : the results of sustainable development activities are seen in indices of company's value assessment.

The hypotheses were verified by evaluating companies which are listed in NASDAQ OMX BALTIC stock exchange and participate in UN Global Compact.

UN Global Compact it's world largest corporate sustainability initiative (UN Global Compact, 2016) in which participate 9000 companies and plus 3000 non-businesses. 44 companies and organizations from Lithuania are participating in this initiative. Only 4 companies from NASDAQ OMX Baltic Stock Exchange are members of UN Global Compact initiative and will be evaluated in research.

\section{The interface of company's sustainable development and company's value}

The concept of company's sustainable development is interpreted as the strategy of business and investment, which aims to use the best business practices to achieve the balance of current and future needs of stakeholders (Artiach et al. 2010). Avota et al. (2015) in the paper presented the views of several authors (Epstein 2008; Lo, Sheu 2007; White 2013) that sustainability "in management research is used as a business approach that creates long term shareholder value and at the same time takes into consideration economic, environmental and social dimensions including corporate governance, human capital management, protection of environment and corporate social responsibility". Seay (2015) described corporate sustainability in the relationship with value creation "an alternative to the traditional growth and profit-maximization model, corporate sustainability also recognizes the importance of growth and profitability, but also requires the pursuit of societal, environmental, and governance goals for long-term value creation and success". Same as Seay (2015) which paper is dedicated to the analyses how the integration of sustainability into business processes and products creates value for all of a company's stakeholders, many authors acknowledge the relevance and linkages between company's sustainable development and company's value. Bell et al. (2012) are determining how to increase companies' economic value through the adoption of sustainability initiatives and state that companies, which have embraced sustainability as part of their corporate culture have gone further and used a "sustainability" framework to look for ways not only to do well by all stakeholders, but to add economic value to the company through entrepreneurial thinking about their processes. Slater and Gilbert (2004) emphasize that sustainable development directly drives (or limits) value creation within a company. Hynds (2013) states that managers must explore how they can enhance their company's position in the marketplace by looking at opportunities to innovate through the lens of sustainability. Looking through the lens of sustainability can have real value.

Sustainability reporting has become a core requirement for many corporations, enabling them to increase their value and sustain long-term profitability (PwC 2004).

Same or very similar theories should be valid for listed companies and the understanding of their value. Lowitt (2011) supports it claiming that sustainable market leaders believe that embracing sustainability will create more value for shareholders and other stakeholders. Eccles et al. (2012) study found that companies that embraced a long-term corporate culture of sustainability outperform their peers in terms of reputation, net income, and stock price.

The abundance of research, both theoretical and applied, suggests there is a relationship between sustainability and value (Warren-Myers 2012).

\section{Company and business indices influenced by sustainable development}

In the report of United Nations Industrial Development Organization (2015) about the disclosure of sustainability, it is claimed that the companies which carefully and properly implement the concept of sustainable development into business strategy and their activities, have the possibility to become more competitive. It would be revealed through better capital and market availability, increased sales, and of course the increased profits and saved operating costs, improved productivity and quality. Talking about the increased profit of a company, the definition profit includes the company's financial indices such as gross profit, operating profit, and net operating profit.

There are many researches about the effect of capital structure on a company's value and the impact of sustainability. The conservation of capital stock as required by the constant capital rule will be more easily achieved the more efficiently capital is used. Thus, companies must aim at high efficiency of capital use if they are to contribute to sustainable development (Figge, Hahn 2005). The concept of sustainable development and the capital approach to sustainability have also been applied by Atkinson (2000). The conservation of capital stock as required by the constant capital rule, which is described as following, - a development must leave the capital stock per capita at least unchanged to meet the normative demand of sustainable development, will be more easily achieved the more efficiently capital is used. Thus, companies must aim at high efficiency of capital use if they are to contribute to sustainable development (Figge, Hahn 2005; Harte 1995; Stern 1997). 

company's value

Sustainable development creates better competitive opportunities and businesses become more attractive not only for consumers but also for investors, which pays big attention to the discount rate or weighted capital costs. According to Nassos (2014) discount rate can be defined as a rate equal to the current share price and the expected cash flows. Companies which not implement sustainable development in their activities will likely have fewer resources, which leads to a higher discount rate. On the contrary, the companies, which are engaged in sustainable development policies and investments related to it, are likely to be more attractive to investors and the demand will increase, consequently the discount rate will be lower. Meanwhile, Martin (2014) believes that sustainable development helps to reduce the cost of business capital and increases corporate efficiency.

\section{Assessment indices to determine the value of listed companies}

It is difficult to assess shares not only because of the features of evaluation, but also for a variety of factors that influence the price in stock market. Hansen, Wernerfelt (1989) showed that internal factors have double impact on the final results of the company comparing to external factors. Evaluation of shares allows to some extent for determining the company's value as a share value does not depend exclusively on demand and supply on the market, but also on many factors which shape its rate starting from valuation of an enterprise by means of different methods up to showing the mechanisms changing the share value in a way increasing its value or underrating it (Parvi 2016). According to Martin (2014), there is a positive correlation between sustainability and the value of the shares on the market. The research indicates that companies that violate environmental requirements have a significant drop in stock prices. Meanwhile, good employee relations and their positive satisfaction due to the company's shares increase in value. Bacidore et al. (1997) state that the indices of companies' value focus on the price change of stock and seek to measure how much the shareholder value increased over a period of time. Lehn and Makhija (1997) examined the degree of correlation between different performance measures and stock market returns. The results reveal that Economic Value Added (EVA) is the most highly correlated measure with stock returns.

EVA is a modern instrument of performance measurement, highlighting the value surplus obtained by shareholders from profits resulting from carrying on current activities, after covering the costs of invested capital and profit tax (Stefan 2016). Petrescu (2008) believes that added value is "the main element in determining certain indices of value creation with major significance in the activity of any entity listed or not on the capital market" and mentions a number of the indices presented above as criteria for performance evaluation. Shil (2009) analysed the application of economic value added and concluded that EVA should not entirely replace the traditional measures, one of which is ROE and has incremental value in monitoring company's performance. ROE is another measure of profitability that focusses on the return on the shareholders' equity. Despite the fact that many companies use EBITDA, its true informative efficacy is the subject of much discussion. EBITDA index is more stable and less affected by various factors, as well gives a possibility to compare companies from different sectors (Alcalde et al. 2013).

From theoretical point of view there are no "bad" or "good" indices, each of them is appropriate for a given situation or business analysis. However, paying attention to the fact that there is no single universally recognized assessment method or index for the value created by sustainable development and analysed companies are listed companies from different economic sectors, which value reflects best in financial indices as share market price, the methods and indices which have direct relation to companies' share price as the value of a company are selected for the further research.

On the basis of literature analysis this paper proposes the following hypothesis:

H1: sustainable development of listed company has an impact on the company's weighted average capital costs, and it has a reflection in company's value.

$\mathrm{H} 2$ : the results of sustainable development activities are seen in indices of company's value assessment.

\section{The relationship between EVA, ROE, EV/EBITDA and company's value created by sustainable development}

The indices EVA, ROE, EV/EBITDA and market capitalization are analysed in order to identify the relationship between sustainable development and components of indices. EVA index was chosen due to the emphasize the appropriateness by wide theoretical justification and experts, when the value of listed companies, which implement sustainable development in their activities, are assessed. Having regard to the advantages of EV/EBITDA index, it represents in the most appropriate way the value of listed companies in a relation to EBITDA. ROE ratio possibly reveals a link between the value and the share price, and indicates whether the actual results of the performance of the company are in line with prior expectations.

\section{EVA and WACC}

The relation between variables and has to be set and a scheme of EVA formula, which is adapted in order to identify the relationship between the company's WACC, EVA and sustainable development. The formula of EVA is used (Copeland et al. 1996):

$$
E V A=E B I T-A * W A C C,
$$


where: $E B I T$ - earnings before interest and taxes; $A$ - asset; $W A C C$ - weighted average cost of capital.

Weighted average cost of capital formula is chosen where equity and debt capital are identified (Nippel 2003):

$$
\mathrm{WACC}=R e^{*} \frac{E}{V}+R d^{*} \frac{D}{V} *(1-T)
$$

where: $R e$ - cost of equity; $E / V$ - equity/total value; $R d$ - cost of debt; $D / V$ - debt/total value; $(1-T)$ - tax adjustment for interest expense.

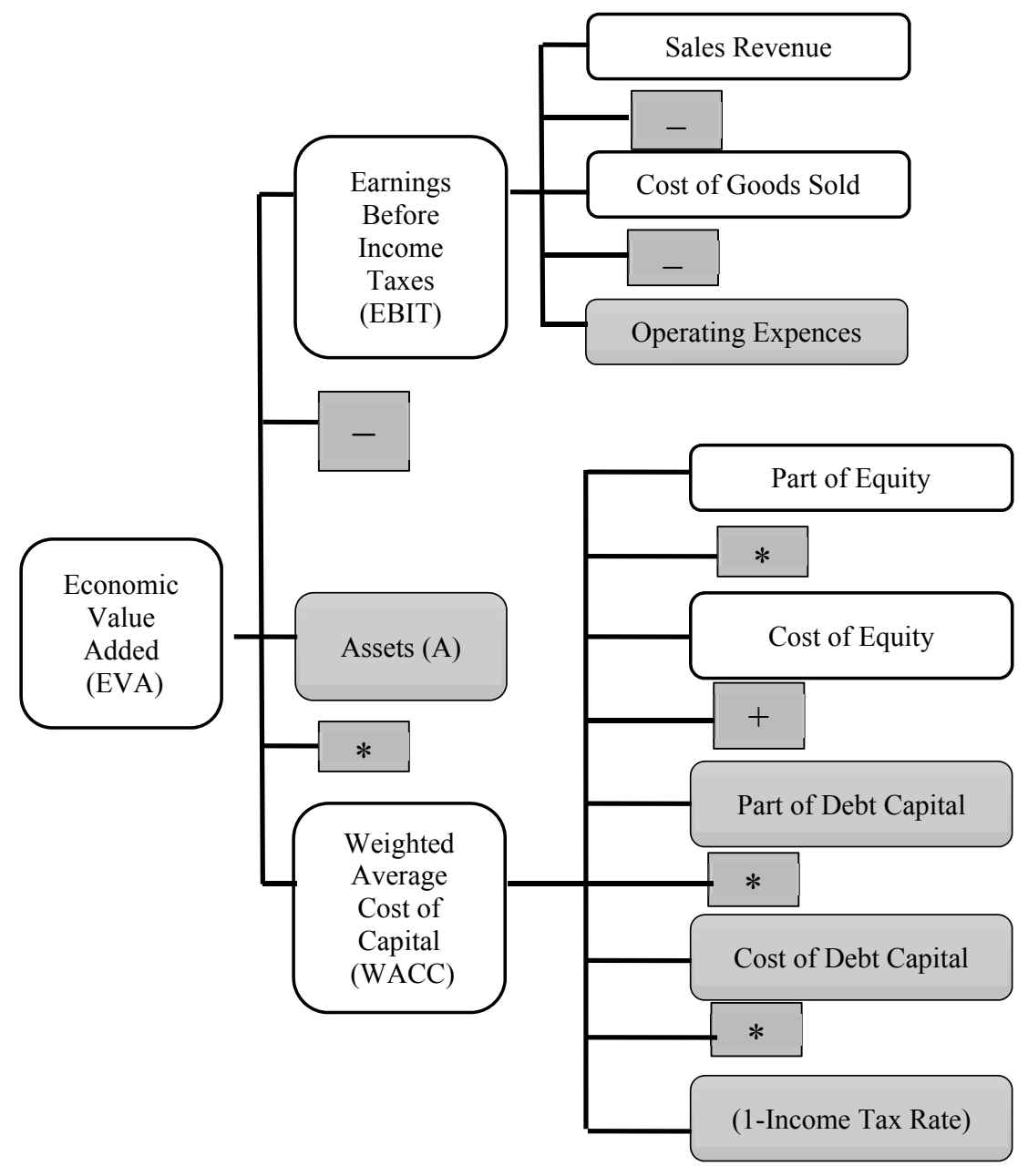

Fig. 1. The relationship between EVA and company's value created by sustainable development (Source: made by authors)

In the Figure 1 the relationship and dependence between variables is clearly visible. Grey colour represents EVA formula components and white colour represents variables, such as sales revenue, cost of goods sold, WACC, part of equity, cost of equity, EBIT and EVA, which could be influenced by sustainable development.

Return on equity (ROE)

Return on equity is calculated by the following formula (Bolek, Wolski 2012):

$$
\mathrm{ROE}=\frac{\text { Net Income }}{\text { Shareholder's Equity }} .
$$

In order to identify how these indices are related to ROE, extended scheme has been drawn (see Fig. 2). 


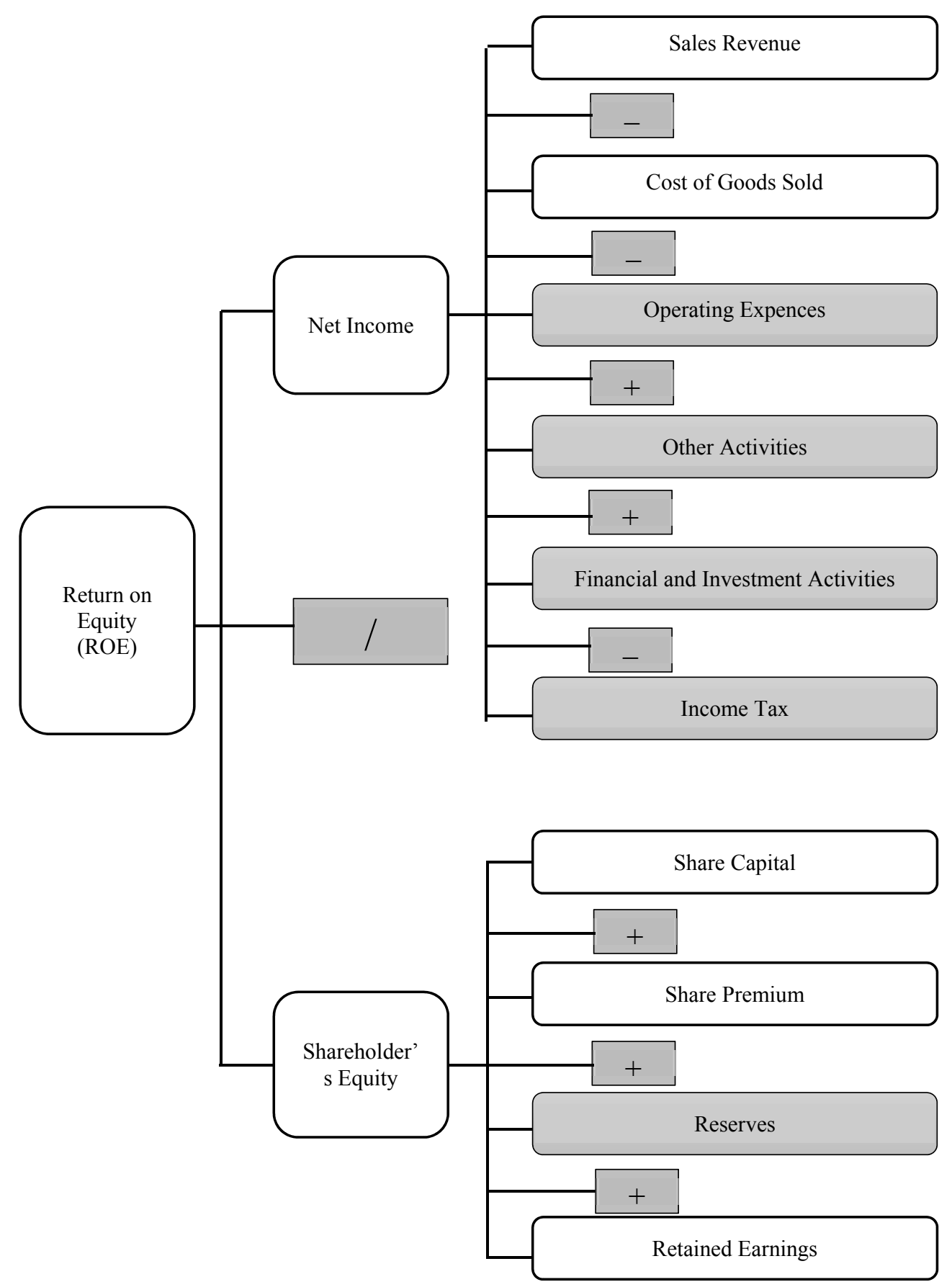

Fig. 2. The relationship between ROE and company's value created by sustainable development (Source: made by authors)

Shareholder's equity expands into four main areas. Three areas of the four are linked to the company's shares as well as sustainable development: share capital and share premium and retained earnings. According to the ideology of sustainable development retained earnings must be positive in order it's activities would be implemented from their own funds and not from external funds.

\section{EV / EBITDA ratio and market capitalization}

In order to determine the value of company very often ratios of comparative value are used. In this paper EV / EBITDA (business value and profit before interest, taxes, depreciation and amortization) ratio is used. In order to assess how the variables of indexes, which are influenced by sustainable development, like sales, operating profit, average capital costs, the price of shares, are related to EV / EBITDA ratio (EV / EBITDA) the extended EV / EBITDA ratio scheme is drawn (see Fig. 3). 


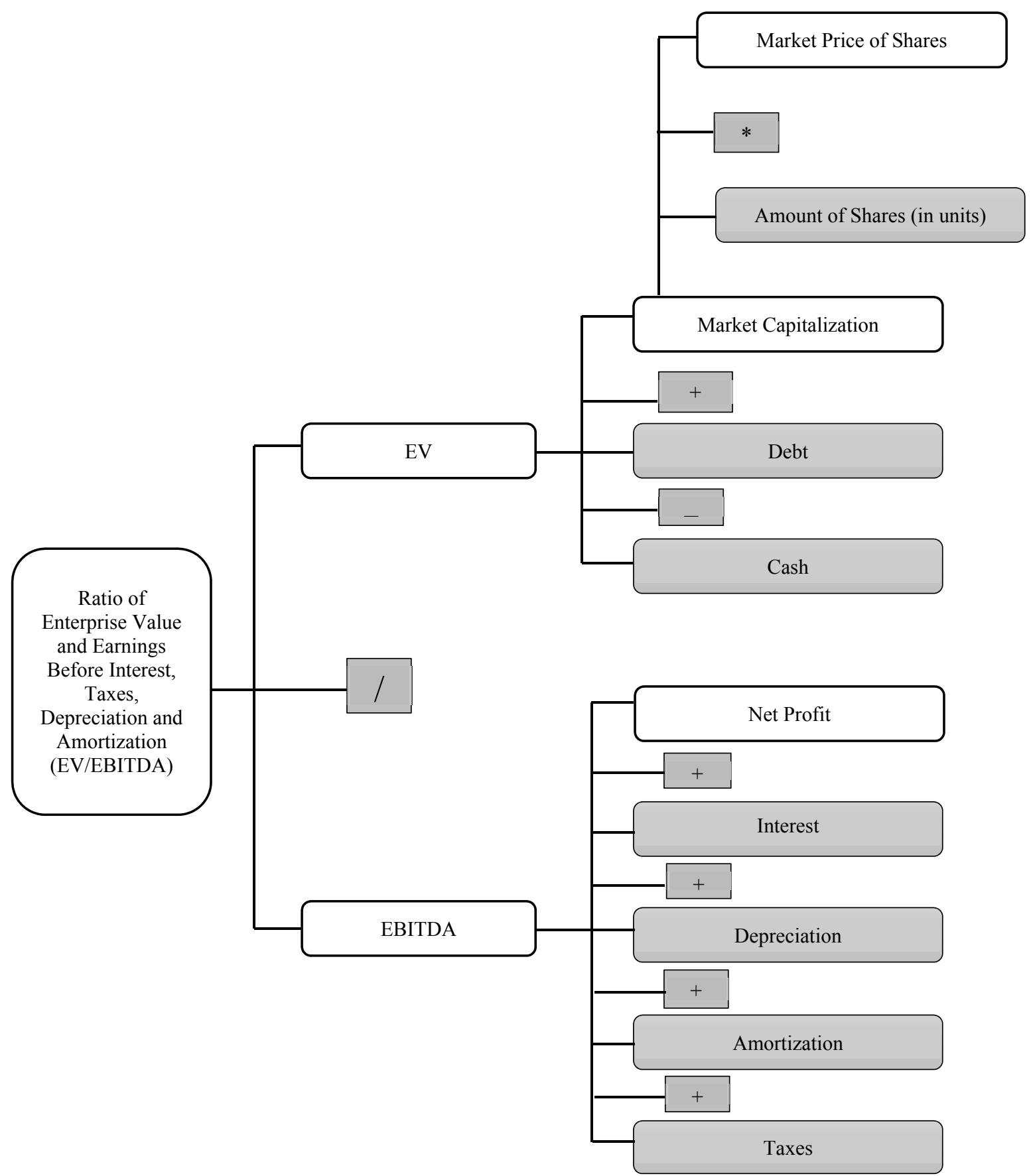

Fig. 3. The relationship between ROE and company's value created by sustainable development (Source: made by authors)

From Figure 3 it is seen that in EBITDA index only one variable, net profit, has a relationship with sustainable development and in EV index, market capitalization index through a variable market price per shares, has an impact.

\section{The verification of hypotheses}

In this paper, the companies which are listed on the NASDAQ OMX Baltic Stock Exchange and participate in UN Global Compact are selected for the research. Totally there are 4 such type of companies in Lithuania: Śiaulių bankas $\mathrm{AB}$, Lietuvos energijos gamyba AB, TEO LT AB and Energijos skirstymo operatorius AB. For further research only three companies, Siauliu bankas AB (in UN Global Compact since 2008-06-19), Lietuvos energijos gamyba AB (in UN Global Compact since 2012-05-23) and TEO LT AB (in UN Global Compact since 2005-06-14), will be selected, because Energijos skirstymo operatorius AB in 2015 December 15 was restructured.

In order to verify the raised hypothesis (H1) - sustainable development of listed company has an impact on the company's weighted average capital costs, and it has a reflection in company's value, - on the basis of the selected 

company's value

companies' financial statements, EVA scheme is evaluated in support of impact of sustainable development on WACC. The assumption is made, that the changes of WACC and its components probably could affect the change of EVA size. For example, increase / decrease in cost of equity, increase / decrease in part of equity, increase / decrease in cost of debt capital, increase / decrease in part of debt capital, increase / decrease in the income tax, have an influence on size of weighted average cost of capital, which changes has an impact on other components of EVA formula and thereby on EVA which defines company's value.

Before carrying out a sensitivity analysis, it is important to set a relationship between WACC, EVA and sustainable development. Companies which are not implementing sustainable development into their activities will have fewer resources, what could affect WACC by increasing it. Meanwhile, companies which implement sustainable development policies and investments related to it are likely to be more attractive to investors, their demand will increase, resulting WACC lowering (Nassos 2014). A sensitivity analysis is performed initiating the variation of WACC by $25 \%$ and the changes of the whole EVA scheme chain can be seen.

The case of TEO LT AB. For TEO LT AB case financial statements from 2015 December 31 (NASDAQ OMX BALTIC 2016) were used. On the basis of study results a sensitivity analysis was performed (see Table 1).

Table 1. Results of WACC and EVA sensitivity analysis. AB TEO LT case (Source: made by authors)

\begin{tabular}{|c|c|c|c|c|c|c|c|}
\hline \multirow{3}{*}{$\begin{array}{l}\text { Parameters for } \\
\text { sensitivity analysis } \\
\begin{array}{l}\text { The weighted cost of } \\
\text { capital }\end{array}\end{array}$} & \multirow{2}{*}{$\begin{array}{c}\begin{array}{c}\text { Variation } \\
(\%)\end{array} \\
25\end{array}$} & \multirow{2}{*}{$\begin{array}{c}\text { New EVA, EUR } \\
28.037,07\end{array}$} & \multicolumn{2}{|c|}{ EVA change, EUR } & \multirow{2}{*}{$\begin{array}{c}\begin{array}{c}\text { EVA relative } \\
\text { change }(\%)\end{array} \\
-6,97\end{array}$} & \multicolumn{2}{|c|}{ Elasticity } \\
\hline & & & - & $2.100,39$ & & - & 0,28 \\
\hline & -25 & $32.237,84$ & & $2.100,39$ & 6,97 & - & 0,28 \\
\hline \multirow{2}{*}{ Cost of equity } & 25 & $28.364,37$ & - & $1.773,08$ & $-5,88$ & - & 0,24 \\
\hline & -25 & $31.910,54$ & & $1.773,08$ & 5,88 & - & 0,24 \\
\hline \multirow{2}{*}{ cost of debt capital } & 25 & $29.810,15$ & - & 327,31 & $-1,09$ & - & 0,04 \\
\hline & -25 & $30.464,76$ & & 327,31 & 1,09 & - & 0,04 \\
\hline \multirow{2}{*}{ Income tax rate } & 25 & $30.195,21$ & & 57,76 & 0,19 & & 0,01 \\
\hline & -25 & $30.079,70$ & - & 57,76 & $-0,19$ & & 0,01 \\
\hline Basic situation & - & $30.137,45$ & & - & & & \\
\hline
\end{tabular}

During sensitivity analysis, the changes of variables only in parts of WACC are initiated. For example, in one case costs of equity of 25 percent are increased and the changes of the whole chain are seen, in another case costs of equity of 25 percent are decreased and the changes of the whole chain are seen. As it can be seen from Table 1, EVA reacts most sensitive to changes in costs of equity. It means that if the cost of capital increase (decrease) by 25 percent, EVA rate decrease (increase) by 5.88 percent. Sensitivity analysis also showed that between WACC, costs of equity, costs of debt capital and EVA an indirect connection exist.

The results show that even the slightest change of WACC variables causes WACC own results and the size of company's economic value added. Consequently, the size of company's value is leaded by the changes of WACC variables.

The case of Šiauliu bankas AB. For AB Siauliu bank case financial statements from 2015 December 31 (NASDAQ OMX BALTIC 2016) were used (see Table 2).

Table 2. Results of WACC and EVA sensitivity analysis. AB Siauliu bankas case (Source: made by authors)

\begin{tabular}{|c|c|c|c|c|c|c|c|c|}
\hline \multirow{3}{*}{$\begin{array}{l}\text { Parameters for } \\
\text { sensitivity analysis } \\
\text { The weighted cost of } \\
\text { capital }\end{array}$} & \multirow{2}{*}{$\begin{array}{c}\begin{array}{c}\text { Variation } \\
(\%)\end{array} \\
25\end{array}$} & \multicolumn{2}{|c|}{ New EVA, EUR } & \multicolumn{2}{|c|}{ EVA change, EUR } & \multirow{2}{*}{$\begin{array}{c}\text { EVA relative } \\
\text { change }(\%)\end{array}$} & \multirow{2}{*}{\multicolumn{2}{|c|}{$\begin{array}{r}\text { Elasticity } \\
7,49\end{array}$}} \\
\hline & & - & $17.361,47$ & - & $11.318,69$ & & & \\
\hline & -25 & & $5.275,92$ & & $11.318,69$ & $-187,31$ & & 7,49 \\
\hline \multirow{2}{*}{ Cost of equity } & 25 & - & $7.597,67$ & - & $1.554,89$ & 25,73 & & 1,03 \\
\hline & -25 & - & $4.487,89$ & & $1.554,89$ & $-25,73$ & & 1,03 \\
\hline \multirow{2}{*}{ cost of debt capital } & 25 & - & $15.806,58$ & - & $9.763,80$ & 161,58 & & 6,46 \\
\hline & -25 & & $3.721,03$ & & $9.763,80$ & $-161,58$ & & 6,46 \\
\hline \multirow{2}{*}{ Income tax rate } & 25 & - & $4.319,75$ & & $1.723,02$ & $-28,51$ & - & 1,14 \\
\hline & -25 & - & $7.765,80$ & - & $1.723,02$ & 28,51 & - & 1,14 \\
\hline Basic situation & - & - & $6.042,78$ & & - & & & \\
\hline
\end{tabular}



company's value

As it can be seen from Table 2, EVA reacts most sensitive to changes in costs of debt capital. It means that if the costs of debt capital increase (decrease) by 25 percent, EVA rate decrease (increase) by 161,58 percent. It can be explained by the fact that AB Siauliu Bank debt capital is more than 90 percent from total assets, that's why costs of debt capital have a decisive impact on WACC.

The case of Lietuvos energijos gamyba AB. For AB "Lietuvos energijos gamyba" same as for AB TEO LT and AB Siauliu bank cases, financial statements from 2015 December 31 (NASDAQ OMX BALTIC 2016) were used. On the basis of study results a sensitivity analysis was performed (see Table 3), during which the variation of WACC by $25 \%$ is initiated and the changes of the whole EVA scheme chain are seen.

Table 3. Results of WACC and EVA sensitivity analysis. AB Lietuvos energijos gamyba case (Source: made by authors)

\begin{tabular}{|c|c|c|c|c|c|c|c|c|}
\hline $\begin{array}{c}\text { Parameters for } \\
\text { sensitivity analysis }\end{array}$ & $\begin{array}{l}\text { Variation } \\
(\%)\end{array}$ & & EVA, EUR & & ange, EUR & $\begin{array}{c}\text { EVA } \\
\text { relative } \\
\text { change }(\%)\end{array}$ & & Elasticity \\
\hline \multirow{2}{*}{$\begin{array}{l}\text { The weighted cost of } \\
\text { capital }\end{array}$} & 25 & - & $32.190,30$ & - & $6.859,66$ & 27,08 & & 1,08 \\
\hline & -25 & - & $18.470,98$ & & $6.859,66$ & $-27,08$ & & 1,08 \\
\hline \multirow{2}{*}{ Cost of equity } & 25 & - & $29.112,27$ & - & $3.781,62$ & 14,93 & & 0,60 \\
\hline & -25 & - & $21.549,02$ & & $3.781,62$ & $-14,93$ & & 0,60 \\
\hline \multirow{2}{*}{ cost of debt capital } & 25 & - & $28.408,68$ & - & $3.078,04$ & 12,15 & & 0,49 \\
\hline & -25 & - & $22.252,60$ & & $3.078,04$ & $-12,15$ & & 0,49 \\
\hline \multirow{2}{*}{ Income tax rate } & 25 & - & $24.787,46$ & & 543,18 & $-2,14$ & - & 0,09 \\
\hline & -25 & - & $25.873,83$ & - & 543,18 & 2,14 & - & 0,09 \\
\hline Basic situation & - & - & $25.330,64$ & & - & & & \\
\hline
\end{tabular}

As it can be seen from Table 3, EVA reacts most sensitive to changes in costs of equity. It means that if the costs of equity increase (decrease) by 25 percent, EVA rate decrease (increase) by 14,93 percent. However, EVA is also sensitive enough to changes in cost of debt capital. This could be related to the fact that Lietuvos energijos gamybos $\mathrm{AB}$ equity capital and debt capital, both have similar parts in the company's assets structure.

In general, it can be said that the hypothesis (H1), - sustainable development of listed company has an impact on the company's weighted average capital costs, and it has a reflection in company's value, - could be accepted. With the help of results of sensitivity analysis an interface of WACC influenced by sustainable development and the size of the EVA was established.

In order to verify the raised hypothesis (H2) - the results of sustainable development activities are seen in indices of company's value assessment, - it should be estimated what value company creates and how the value has been changed during the period 2011-2015. EVA index represents the value of company and late it results are compared to changes in the value of shares, which are expressed using EV/EBITDA, ROE and market capitalization indices (see Table 4, Table 5, Table 6).

Table 4. Indices of Lietuvos energijos gamyba AB for period 2011-2015 (Source: made by authors)

\begin{tabular}{llrrrrr}
\hline \multicolumn{1}{c}{ Indices } & Units of Measurement & 2011 & 2012 & 2013 & 2014 & 2015 \\
\hline Market Capitalization & Thousands, EUR & 50807 & 44456 & 50807 & 69859 & 63508 \\
\hline EV/EBITDA & Times & 32 & 16 & 9 & 8 & 10 \\
\hline EVA & Thousands, EUR & -57160 & -44132 & -11821 & 9906 & -25331 \\
\hline ROE & Percentage (\%) & 0,09 & 2,20 & 7,68 & 10,96 & $-0,89$ \\
\hline
\end{tabular}

As it is seen from Table 4 value of Lietuvos energijos gamyba AB was negative, apart from 2014. However, it should be noted, that from 2012 till 2014 value was growing. It could be linked to event when in 2012 Lietuvos energijos gamyba AB joined UN Global Compact and undertook to implement sustainable development into its activities.

Index of market capitalization confirms that not only economic added value created by Lietuvos energijos gamyba $\mathrm{AB}$, but value of shares in 2014 were the biggest and reached almost 70 million euros. The growth of stock value could cause the fact that Lietuvos energijos gamyba AB in 2014 approved a new version of the collective agreement, which ensures a more favourable package of social benefits for the company's employees as it is required by the Labour code of the Republic of Lithuania.

Analysing the ROE, it should be noted that it also, as the analysed indexes before, was growing and 2014 it reached the highest value - 10.96 percent. However, in 2015 it dropped significantly and became negative, since 

company's value

Lietuvos energijos gamyba AB has suffered a loss. Also, the relative decrease of indexes in 2015 was caused by singed delivery and acceptance certificate for part of business, with which has successfully completed one of the company's operational chain unbundling program.

Summarizing it can be said that changes of indexes of Lietuvos energijos gamyba AB are influenced by sustainable development activities and it is reflected in company's created value.

Table 5. Indices of TEO LT AB for period 2011-2015 (Source: made by authors)

\begin{tabular}{llrrrrr}
\hline \multicolumn{1}{c}{ Indices } & Units of Measurement & 2011 & 2012 & 2013 & 2014 & 2015 \\
\hline Market Capitalization & Thousands, EUR & 497163 & 512700 & 613686 & 477743 & 600092 \\
\hline EV/EBITDA & Times & 5,37 & 5,00 & 6,55 & 6,09 & 7,92 \\
\hline EVA & Thousands, EUR & 28974 & 30520 & 31349 & 30994 & 30137 \\
\hline ROE & Percentage (\%) & 14,84 & 15,22 & 14,36 & 15,85 & 14,56 \\
\hline
\end{tabular}

As it is seen from Table 5 during the analysed period EVA was positive. The greatest value is reached in 2013, when EVA reached more than 31 million euros. In 2015 EVA decreased due to decrease of dividends per share, which in 2015 the rate was only 0.01 euros per share, while in 2014 this rate was 0.068 euros per share.

Market capitalization index during the analysed period was positive, however in 2014 this index comparing to 2013 decrease by 22 percent. This could be the result of the previously mentioned changes in the company's share capital. However, it should be noted that in 2015 market capitalization has risen to 600 million euros and almost reached level of 2013. It could be influenced by the fact that in 2015 investors welcomed the company's intention to merge operations with another company, Omnitel AB, which is also implement sustainable development in its activities. Also, the growth of indexes in 2015 was stimulated by CV-Online company, which organize a survey "Top employer 2014" and TEO LT AB named as the best employer in the IT category. Furthermore, in 2015 TEO LT AB with SEB Investment Management entered into a contract for TEO LT employee pension in III pillar pension funds.

Meanwhile, the EV/EBITDA revealed that the ratio of TEO LT AB company's value and EBITDA for period 2011-2015 is not constant. The decrease of this index in 2014 could also be caused by analysed company's decision to reduce the number of shares.

Table 6. Indices of Šiaulių bankas AB for period 2011-2015 (Source: made by authors)

\begin{tabular}{llrrrrr}
\hline \multicolumn{1}{c}{ Indices } & Units of Measurement & 2011 & 2012 & 2013 & 2014 & 2015 \\
\hline Market Capitalization & Thousands, EUR & 70457 & 58714 & 65000 & 78300 & 91226 \\
\hline EV/EBITDA & Times & 30 & 30 & 39 & 37 & 43 \\
\hline EVA & Thousands, EUR & -36182 & -35792 & -50864 & -33288 & -6043 \\
\hline ROE & Percentage (\%) & 4,43 & 4,17 & 5,71 & 11,04 & 17,38 \\
\hline
\end{tabular}

During the analysed period, Šaulių bankas AB does not create added value, since the EVA index is negative. However, from 2013 onwards the value of the bank is growing every year.

Siaulių bankas AB according to the funded projects has become a house renovation financing leader in Lithuania in 2014. At the end of 2014 Šiaulių bankas AB was the bank which accepted the biggest number of applications, under the funding program JESSICA in Lithuania and became the first partner from the country to the European Investment Bank (EIB) providing soft loans for renovation (AB Šiaulių banko socialinès atsakomybès ataskaita 2014).

The calculated share value using the index of market capitalization, every year since 2012 grew and in 2015 it reached 91 million euros. It was influenced by each year newly formed authorized capital, since the market price of the shares in a period of 2011-2015 changed slightly and was 30 euro cents per share.

Also, the improvement of analysed indices of the Šiaulių bankas AB contributed to the fact that two companies were joined to the bank. As well Moody's Investors Service (2015) announced that it increased the Šiaulių bankas AB long-term credit rating from $\mathrm{B} 1$ to $\mathrm{Ba} 2$. That shows that the perspective of long-term credit rating is stable.

Also, Śaulių bankas AB is active in the prevention of corruption. International business and financial magazine "Global Finance" in 2014 awarded Šiaulių bankas AB and recognized it as the safest bank in Lithuania.

To summarize the results, the table was created, which presents the analysed companies and indices. The changes of indexes which could be related to sustainable development activities are marked. 

company's value

Table 7. The summary of indices and companies, where the results of sustainable development are seen in indices of company's value assessment (Source: made by authors)

\begin{tabular}{lcccc}
\hline \multicolumn{1}{c}{ Companies } & EVA & EV/EBITDA & ROE & Market Capitalization \\
\hline TEO LT AB & $\mathrm{X}$ & & $\mathrm{X}$ & $\mathrm{X}$ \\
\hline Lietuvos energijos gamyba AB & $\mathrm{X}$ & $\mathrm{X}$ & $\mathrm{X}$ & $\mathrm{X}$ \\
\hline Šiaulių bankas AB & $\mathrm{X}$ & & $\mathrm{X}$ & \\
\hline
\end{tabular}

Generally, it should be said that the second hypothesis was affirmed not in all the analysed companies. The results of research revealed that the hypothesis (H2) was affirmed in TEO LT AB and Lietuvos energijos gamyba AB cases. It was found that the variation of indices is influenced by sustainable development activities. Meanwhile, in Šiauliu bankas $\mathrm{AB}$ case, the connection of indices and sustainable development was affirmed only in two indices: EVA and ROE.

\section{Conclusions}

The results of the analysis of scientific literature support the view that the activities of sustainable development may be reflected in the value of listed companies and sustainable development primarily affects the company's financial indices, such as sales, cost, profit, capital, shares. Also, the companies, which properly integrate the concept of sustainable development, could become more competitive and more attractive for investors. What is very important for listed companies, as their value is perceived through the shares. Summarizing the theoretical analysis, it can be said that the relationship between activities of sustainable development of listed companies and companies' value exists. In order to verify the raised hypothesis (H1), which states that sustainable development of listed company has an impact on the company's WACC, and it has a reflection in company's value, on the basis of the selected companies' financial statements, EVA scheme is evaluated in support of impact of sustainable development on WACC. With the help of results of sensitivity analysis an interface of WACC influenced by sustainable development and the size of the EVA was established and the hypothesis (H1) could be affirmed.

The indices EVA, ROE, EV/EBITDA and market capitalization were analysed in order to identify the relationship between sustainable development and components of indices and verify the hypothesis (H2) that the results of sustainable development activities are seen in indices of company's value assessment. The hypothesis (H2) was affirmed not in all the analysed companies. The results of research revealed that hypothesis (H2) were affirmed in TEO LT AB and Lietuvos energijos gamyba AB cases. It was found that the variation of indices is influenced by sustainable development activities. Meanwhile, in Šiaulių bankas AB case, the connection of indices and sustainable development was affirmed only in two indices: EVA and ROE.

\section{References}

Alcalde, A.; Fávero, L. P. L.; Takamatsu, R. T. 2013. EBITDA margin in Brazilian companies Variance decomposition and hierarchical effects, Contaduria y Administración 58(2): 197-220. https://doi.org/10.1016/S0186-1042(13)71215-4

Artiach, T.; Lee, D.; Nelson, D.; Walker, J. 2010. The determinants of corporate sustainability performance, Accounting and Finance 50: 31-51. https://doi.org/10.1111/j.1467-629X.2009.00315.x

Atkinson, G. 2000. Measuring corporate sustainability, Journal of Environmental Planning and Management 43(2): $235-252$. https://doi.org/10.1016/0167-7187(95)00499-8

Avota, S.; McFadzean, E.; Peiseniece, L. 2015. Linking personal and organisational values and behaviour to corporate sustainability: a conceptual model, Journal of Business Management 10: 124-133.

Bacidore, J. M.; Boquist, J. A.; Milbourn, T. T.; Thakor, A. V. 1997. The search for the best financial performance measure, Financial Analysts Journal 5/6: 11-20. https://doi.org/10.2469/faj.v53.n3.2081

Bell, J.; Soybel, V. E.; Turner, R. M. 2012. Integrating sustainability into corporate DNA, The Journal of Corporate Accounting \& Finance 23(3): 71-82. https://doi.org/10.1002/jcaf.21755

Bolek, M.; Wolski, R. 2012. Profitability or liquidity: influencing the market value: the case of Poland, International Journal of Economics and Finance 4(9): 184-185. https://doi.org/10.5539/ijef.v4n9p182

Copeland, T.; Koller, T.; Murrin, J. 1996. Valuation: Measuring and Managing the Value of Companies. $2^{\text {nd }}$ ed. John Wiley \& Sons, Inc.

Eccles, R. G.; Ioannou, I.; Serafeim, G. 2012. The Impact of corporate sustainability on organizational processes and performance [online], [cited 05 December 2016]. Available from Internet: http://www.nber.org/papers/w17950.pdf

Epstein, M. J. 2008. Making sustainability work: best practices in managing and measuring corporate social, environmental and economic impacts. Sheffield: Berrett-Koehler Publishers.

Figge, F.; Hahn, T. 2005. The cost of sustainability capital and the creation of sustainable value by companies, Journal of Industrial Ecology 9(4): 47-58. https://doi.org/10.1162/108819805775247936 
Hansen, G. S.; Wernerfelt, B. 1989. Determinants of firm performance: the relative importance of economic and organizational factors, Strategic Management Journal 10(5): 399-411. https://doi.org/10.1002/smj.4250100502

Harte, M. J. 1995. Ecology, sustainability, and environment as capital, Ecological Economics 15: 157-164. https://doi.org/10.1016/0921-8009(95)00043-7

Hynds, E. 2013. Viewing innovation through the sustainability lens, Research-Technology Management 56: 10-12. https://doi.org/10.5437/08956308X5602009

Lehn, K.; Makhija, A. K. 1997. EVA, accounting profits, and CEO turnover: an empirical examination 1985-1994, Journal of Applied Corporate Finance 10(2): 90-96. https://doi.org/10.1111/j.1745-6622.1997.tb00139.x

Lo, S. F.; Sheu, H. J. 2007. Is corporate sustainability a value-increasing strategy for business?, Corporate Governance 15(2): 345 358. doi:10.1111/j.1467-8683.2007.00565

Lowitt, E. 2011. The future of value: how sustainability creates value through competitive differentiation. San Francisco, CA: Jossey-Bass.

Martin, B. 2014. Shares prices boosted by corporate sustainability policies [online], [cited 11 November 2016]. Available from Internet: http://www.telegraph.co.uk/finance/markets/11096221/Shares-prices-boosted-by-corporate-sustainabilitypolicies.html

NASDAQ OMX BALTIC. 2016. Baltic equity list [online], [cited 11 December 2016]. Available from Internet: http://www.nasdaqbaltic.com/market/?lang=lt

Nassos, G. 2014. How sustainability improves shareholder value [online], [cited 18 January 2017]. Available from Internet: https://www.greenbiz.com/blog/2014/09/11/how-sustainability-improves-shareholder-value

Nippel, S. F. 2003. Unternehmensbewertung mit dem WACC-Verfahren: Steuern, Wachstum und Teilausschüttung, Zeitschrift für betriebswirtschaftliche Forschung 55: 401-422.

Parvi, R. 2016. Valuation of shares and their fair value of the companies listed on the fuel sector quoted on the Warsaw stock exchange in Poland within 2007-2016, in $6^{\text {th }}$ Multidisciplinary Academic Conference, February 2016.

Petrescu, S. 2008. Analiza si diagnostic financiar-contabil: ghid theoretic si aplicativ. Bucharest: Editura CECCAR.

PwC. 2004. PricewaterhouseCoopers, The Corporate Responsibility Report, Discussion with PwC Managing Partner: Willem Bröcker [online], [cited 11 December 2016]. Available from Internet: http://www.zeimer.com/pdf/CRR_Vol1_Summer04.pdf

Seay, S. S. 2015. How incorporating a sustainable business model creates value, Business Studies Journal 7(1).

Shil, N. C. 2009. Performance measures: an application of economic value added international, Journal of Business and Management 4(3): 169-177. https://doi.org/10.5539/ijbm.v4n3p169

Slater, A.; Gilbert, S. 2004. The evolution of business reporting: make room for sustainability disclosure, Environmental Quality Management 14(1): 41-48. https://doi.org/10.1002/tqem.20024

Stefan, I. O. 2016. The added value created by companies listed on bucharest stock exchange: trends and perspectives, Audit Financiar 8(140): 875-896.

Stern, D. I. 1997. The capital theory approach to sustainability: a critical appraisal, Journal of Economic Issues 31(1): 145-173. https://doi.org/10.1080/00213624.1997.11505895

United Nations Industrial Development Organization. 2015. What is CSR? [online], [cited 18 January 2017]. Available from Internet: http://www.unido.org/en/what-we-do/trade/csr/what-is-csr.html

Warren-Myers, G. 2012. The value of sustainability in real estate: a review from a valuation perspective, Journal of Property Investment and Finance 30(2): 115-144. https://doi.org/10.1108/14635781211206887

White, M. 2013. I know it when I see it, Ecological Economics 86(2-3): 213-217 https://doi.org/10.1016/j.ecolecon.2012.12.020 